\title{
Complex interactions of a deposit feeder with its resources: roles of density, a competitor, and detrital addition in the growth and survival of the mudsnail Hydrobia totteni
}

\author{
Jeffrey S. Levinton \\ Department of Ecology and Evolution`, State University of New York at Stony Brook, Stony Brook, New York 11794, USA \\ and \\ Laboratoire Arago, F-66650 Banyuls-Sur-Mer, France
}

\begin{abstract}
Balanced experiments varying detrital input, snail density, and presence of a competing mudsnail demonstrate complex effects on the growth and survival of Hydrobia totteni (Prosobranchia, Hydrobiidae). Although addition of detritus derived from Ulva initially depressed diatom standing stock, an eventual subsidy is reflected in increased snail growth. Both $H$. totteni density and presence of the competitor decrease snail growth and survival; a significant proportion of this effect is transmitted via microalgal depression, but intraspecific and interspecific interference is also important. $H$. totteni populations are probably strongly affected by both interspecific and intraspecific competition, as diatom abundances and experimental animal densities in the laboratory are within the ranges observed in the field. The indirect effect of detritus addition on microalgal growth may be important in the economy of deposit feeders, due to the common winter abundance and late spring decay of the sea lettuce Ulva rotundata.
\end{abstract}

\section{INTRODUCTION}

The study of organisms living in soft sediments has recently followed 2 directions that have been rarely combined. First, several experimental studies have demonstrated interference competition among trophic groups or species (Rhoads \& Young 1970, Woodin 1974, Levinton 1970, Peterson 1977). These studies use laboratory manipulations or field caging to estimate the degree of successful larval settlement, densitydependent or interspecifically caused emigration, and intraspecific and interspecific effects on growth. Alternatively, and for the most part, efforts have been concentrated upon trophic aspects of deposit feeders living in soft sediments. This research program includes 3 different subdisciplines: (a) food source of deposit feeders (e.g. Zobell \& Feltham 1938, Newell 1965, Fenchel 1970, Hargrave 1970, Levinton \& Bianchi 1981); (b) the role of detritus in deposit-feeding systems (e.g. Tenore et al 1979, Hanson 1980, Findley \&

\footnotetext{
- Address for correspondence
}

Tenore 1982, Tenore et al. 1982, Lopez \& Cheng 1983); and (3) the behavior of deposit-feeders as a function of particle size (Whitlatch 1974, Fenchel 1975, Levinton 1980) or food quality (Cammen 1980, Taghon \& Jumars 1984).

An understanding of community structure in mudflat organisms requires a combination of the 2 approaches, as it has become clear that deposit feeders are often regulated by spatial interference on the interspecific (Levinton 1977, Race 1982, Levinton \& Stewart 1982, Brenchley \& Carlton 1983) and intraspecific (e.g. Levinton 1979) levels. But food limitation is also apparently an important factor, at least in deposit-feeding gastropods (Fenchel \& Kofoed 1976, Levinton \& Bianchi 1981). The latter consideration requires a research program that considers both microorganisms and detrital inputs, as both may be important as food sources (Levinton et al. 1984a).

It is the purpose of this study to consider a system whose natural history is well known, but whose interactions among the factors described above have not been investigated in combination. In mud flats 
adjoining Spartina alterniflora marshes on Long Island New York, the hydrobiid gastropod Hydrobia totteni, ca. $3 \mathrm{~mm}$ in length, occurs commonly with the nassariid gastropod Ilyanassa obsoleta. In summer, the two species are zoned in the intertidal, with $H$. totteni occupying the higher portion of the intertidal (Levinton \& Bianchi 1981). The transition from one species to another can occur over a very sharp border, perhaps indicating the importance of interference, but cases of broad overlap are also common. A companion paper (Levinton et al. 1984b) will discuss interference interactions that may lead to zonation, but here I ask what the effects of coexistence might be on $H$. totteni.

The trophic aspects of the mudflat require a consideration of microbial abundance and detrital inputs. Bianchi \& Levinton (1984) showed that the particulate matter deriving principally from the cordgrass Spartina alterniflora is not likely to be of importance in the food of Hydrobia totteni. Winter blooms of the sea lettuce, Ulva rotundata, however, may be of greater importance. In some years, $U$. rotundata covers the lower and middle parts of the mudflat at Flax Pond, New York and gradually decays in situ in the late spring ( $J$. Levinton, unpubl.). How might this decay cycle affect nutrition and growth of Hydrobia totteni and other deposit feeders?

\section{MATERIALS AND METHODS}

I used a combined field and laboratory experimental approach to study the effects of detrital input, the presence of Ilyanassa obsoleta, and variations in $\mathrm{Hy}$ drobia totteni density on the growth and mortality of the latter and on the standing stocks of benthic bacteria and diatoms. Experiments are required, as $H$. totteni abundance (Wells 1978) and microbial abundance (Dale 1974) are both usually correlated with several environmental variables, making simple inferences impossible. Our research was done on a mudflat adjacent (northeastward) to the Flax Pond Marine Laboratory (Marine Sciences Research Center, State University of New York), at Old Field, New York. Using a $0.5 \mathrm{~mm}$ sieve we collected $H$. totteni for laboratory experiments; $I$. obsoleta was collected by hand from the edges of tidal creeks.

Field experiment. In June-July 1983, cages in the mid-intertidal zone were established with different established levels of Ulva rotundata detritus $(0,208$ or $416 \mathrm{~g}$ dry weight $\mathrm{m}^{-2}$ ), and Ilyanassa obsoleta (density 0 or 283 snails $\mathrm{m}^{-2}$ ). This experiment required 6 treatments; we used 3 replicates each. $U$. rotundata was collected live, placed in a Waring blender for 3 to 5 min and was then dried and mixed with sediment before being placed in the field plots. We used circular filter cages of $0.12 \mathrm{~m}^{2}$ (ca. $12 \mathrm{~cm}$ high) with a 6 to $8 \mathrm{~mm}$ mesh that prevented loss or gain of $I$. obsoleta, but permitted relatively free exchange of the smaller $H y$ drobia totteni. The intermediate UIva rotundata treatment corresponds approximately to the average standing stock of $U$. rotundata at its peak in the winter of 1982-1983 (S. Stewart, unpubl.). The $l$. obsoleta density used corresponds to about $3 \times$ the usual highest background levels in this particular flat (Levinton et al. 1984b), though much higher densities can be found in this area (J. Levinton, unpubl.). After the cages were installed and the $I$. obsoleta added, ground $U$. rotundata was added as appropriate, resulting in 6 randomly arrayed treatments with 3 replicates each. After $17 \mathrm{~d}, 6 \mathrm{~mm}$ diameter cores $\times 5 \mathrm{~mm}$ deep were taken ( 3 cage $^{-1}$ ) for counts of bacteria and diatoms. The epifluorescence methodology described in Levinton \& Bianchi (1981) was used for all counts, though dilution factors differed slightly. The experiment was repeated in the fall of 1984 , but only the higher $U$. rotundata detritus addition was employed. Observations were made after 30 and $60 \mathrm{~d}$. The experiment was balanced and could therefore be analyzed by multiway analysis of variance with fixed treatment effects (Model I). We used the means from each replicate for the analyses, and assumed that variation among microbial counts within a replicate $(2$ cores with 20 grids each) represented sampling error.

Laboratory experiment. Prior work, combined with our field experiments and seasonal sampling (Levinton et al. 1984b), showed that it was impractical to use the field experimental approach described above to study effects on Hydrobia totteni growth and survival. Cages that enclose the diminutive $H$. totteni (adult length is maximally $3 \mathrm{~mm}$ in Flax Pond; Levinton \& Bianchi 1981) would be of a mesh size small enough to alter severely the flow regime and collect fine particulate organic material. Recently discovered seasonal vertical migrations in the natural population (Levinton et al. 1984 b) also make such studies impractical, as 3 to 4 mo are required to get useful growth data (Levinton \& Bianchi 1981). We therefore resorted to a laboratory approach that attempted to mimic field conditions, minus tidal inundation and stirring.

Flax pond sediment was placed to a depth of $5 \mathrm{~mm}$ in Petri dishes of $14 \mathrm{~cm}$ diameter in a recirculating seawater system and kept at approximately $18^{\circ} \mathrm{C}$ (Levinton \& Bianchi, 1981). We used juvenile Hydrobia totteni that recruited in the summer of 1984 and were about 2 mo old at the start of the experiment, and adult Ilyanassa obsoleta, ca $2 \mathrm{~cm}$ long, in the experiments. We employed the 3 levels of Ulva rotundata $(0,3.2,6.4$ $\mathrm{g}$ dish $^{-1}$, or $0,208,416 \mathrm{~g} \mathrm{~m}^{-2}$ ) addition corresponding to the field experiment, 2 levels of $H$. totteni density (0.5 and 2 snails $\mathrm{cm}^{-2}$ ), and 2 levels of $I$. obsoleta 
Table 1. Standing stock of bacteria (for each treatment, $n=3)$ and diatoms $(n=6)$ in field sediments as a function of varying density of Ilyanassa obsoleta and inputs of dried sea lettuce Ulva rotundata. Two-way analysis of variance demonstrates the degree of significant factor-related heterogeneity

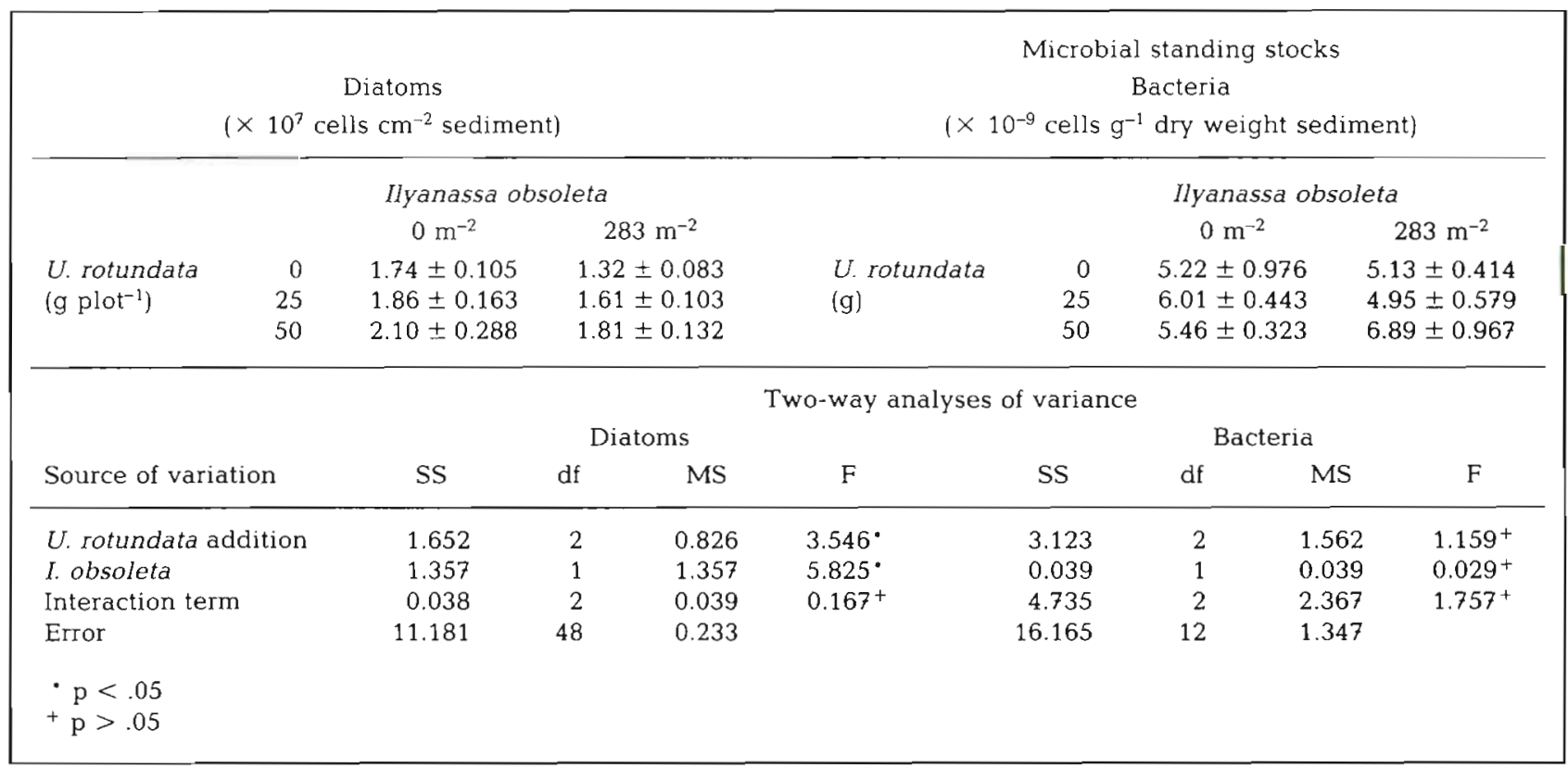

density ( 0 and 150 snails $\mathrm{m}^{-2}$ ). These levels required 12 different combinations (with 4 replicates each) to produce a balanced experiment of 48 replicates, amenable to a simple analysis of variance. Sediment was prepared with various treatments of $U$. rotundata and kept under lights (Levinton \& Bianchi 1981) for $1 \mathrm{wk}$, after which various snail densities were fixed as appropriate. The location of treatments was randomized within the aquarium with respect to position to water source, light, and aquarium box. After finding the bacteria standing stocks did not vary significantly among the factors for the first 3 sampling periods, we continued to count diatoms only as above at 0 ( $3 \mathrm{~d}$ after start), $3,6,10$, and $14 \mathrm{wk}$. At the end of the experiment, we measured shell lengths (a good estimator of weight) of $152 H$. totteni from each treatment and estimated mortality from each replicate. Starting $H$. totteni shell length was $2.47 \mathrm{~mm}(\mathrm{~N}=58)$.

\section{RESULTS}

\section{Field experiments}

Table 1 shows the effect of Ilyanassa obsoleta presence and of Ulva rotundata detritus addition in the field cages after $10 \mathrm{~d}$ in early summer. A 2 way analysis of variance shows for diatoms that both treatment effects were significant $(p<.05)$, with no significant interaction effect. $I$. obsoleta reduced the diatom counts by about $20 \%$. The greatest $U$. rotundata addi- tion treatment increased diatom standing stock to the same degree. In contrast, no significant effect on bacterial counts of either $I$. obsoleta presence or detritus addition was found. It may very well be that bacterial productivity was affected, but we did not measure this.

This experiment was repeated in the fall with somewhat differing results. Cages were set up at the end of September, 1984 and sampled 30 and 60 d later. Nearly all the variance between the 2 sampling times could be accounted by a temporal increase in diatom abundance, perhaps related to a slowing of grazing as temperatures declined. An analysis of variance showed no significant effect of Ilyanassa obsoleta $(p=.60)$ and a nearly significant effect of detritus addition $(\mathrm{p}=.08)$. In the background field population, I. obsoleta retreated below mean low water. The temporal increase in diatoms apparently swamped out the other effects seen in the previous experiment.

\section{Laboratory experiment}

An analysis of variance for benthic diatom counts after 14 wk (Fig. 1) shows a barely significant variance component (Table 2) for Ulva rotundata detritus addition $(\mathrm{p}=.06)$, but a strongly significant component for Hydrobia totteni density $(\mathrm{p}=.01)$ and for Ilyanassa obsoleta presence $(p<.001)$. Diatom abundance was highest at $14 \mathrm{wk}$ in both the intermediate and high detritus additions (Fig. 1), but was always lower in the treatments without $I$. obsoleta. When $I$. obsoleta was 


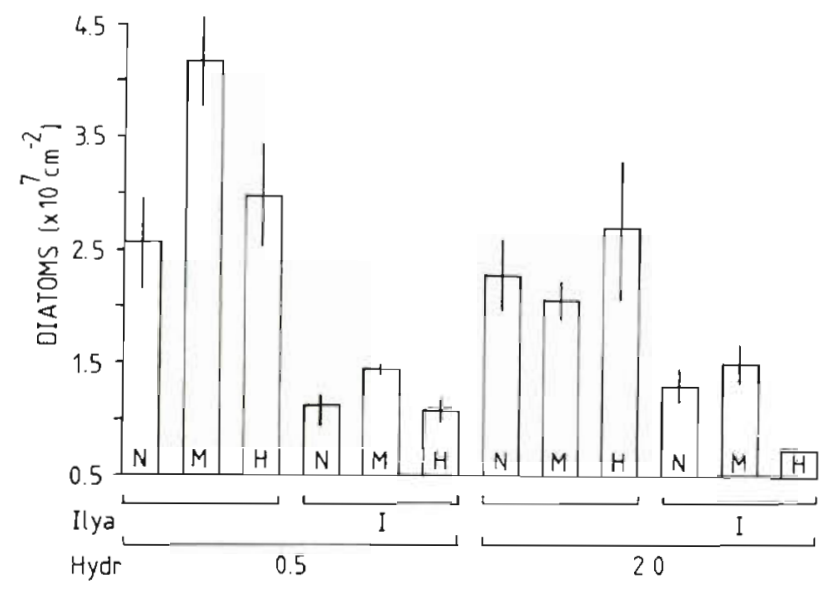

Fig. 1. Diatom standing stock after $14 \mathrm{wk}$ as a function of Hydrobia totteni density, presence of the larger gastropod Ilyanassa obsoleta, and varying additions of Ulva rotundata detritus $\left(\mathrm{N}=\right.$ no addition, $\mathrm{M}=3.2 \mathrm{~g} \mathrm{dish}^{-1}, \mathrm{H}=6.4 \mathrm{~g}$ dish $^{-1}$ ). See Table 2 for statistical analysis

absent, diatom standing stock was greater at low $H$. totteni density, but there was no difference in the presence of $I$. obsoleta, which was probably the major controller of diatom biomass. There was also a statistically significant interaction effect $(p<.05)$ among the several factors, reflecting a strong effect of detritus addition, which will be discussed below. In the first three samplings $(0,3$, and $6 \mathrm{wk})$ bacterial counts were found to be unrelated to any of the experimental treatments (Table 3).

Increase in Hydrobia totteni body size over $14 \mathrm{wk}$ was significantly related (Table 2) to Ulva rotundata addition, $H$. totteni density, and Ilyanassa obsoleta presence ( $\mathrm{p}<.001$ in all cases), but $H$. totteni density was by far the greatest contributor to the overall variance in growth. Both $H$. totteni density and $I$. obsoleta presence depressed $H$. totteni growth (Fig. 2). The effect of $U$. rotundata addition was somewhat more complex. At a density of 2.0 snails $\mathrm{cm}^{-2}$, and at 0.5 snails $\mathrm{cm}^{-2}$ with $I$. obsoleta, growth was greatest at the highest detritus level. At 0.5 snails $\mathrm{cm}^{-2}$ without $I$. obsoleta, growth was greatest at intermediate detritus addition. Survival of $H$. totteni (Fig. 3) was related significantly to its density $(\mathrm{p}<.001)$ and $I$. obsoleta presence $(\mathrm{p}<.01)$, but was not related to detritus addition. As shown in Fig. 3, H. totteni density contributed the most to the variance in survival.

Fig. 4 shows the relation between diatom counts and Hydrobia totteni growth over the 12 treatments, demonstrating a significant positive correlation ( $\mathrm{r}=$ .61, $\mathrm{p}<.05$ ). This is surprising, given the variety of treatments, and raises the possibility that all factors affect $H$. totteni growth at least partially by changing diatom abundance. As mentioned above, increased $H$. totteni density and Ilyanassa obsoleta presence both reduced diatom counts. But the effect of Ulva rotundata is not as direct, as maximum diatom abundance is not always found at the highest $U$. rotundata addition. We must follow the time course of diatom abundance under the various treatments to understand the complexity.

Fig. 5 illustrates the effect of Ulva rotundata detritus addition in the first 3 sampling periods. At 'zero' weeks ( 1 wk after detrital treatments were set up, but before snails were added), there is a strong negative effect of $U$. rotundata detritus addition on diatom abundance. This effect remains after $6 \mathrm{wk}$. Fig. 6, 7 and 8 show diatom abundances for the various snail treatments under no, intermediate and high $U$. rotundata detritus addition, respectively. With no detritus addition, the initial high diatom counts gradually decrease as the result of grazing and reach a lower plateau in the treatments without Ilyanassa obsoleta, probably as the result of a balance between grazing and diatom

Table 2. Three-way analysis of variance for diatom standing stocks and growth of Hydrobia totteni after 14 wk in the laboratory, as a function of variation in Ulva rotundata detritus, Ilyanassa obsoleta presence, and variation in $H$. totteni density

\begin{tabular}{|c|c|c|c|c|c|c|c|c|c|}
\hline \multicolumn{5}{|c|}{ Diatoms } & \multicolumn{5}{|c|}{ Hydrobia growth } \\
\hline Source of variation & SS & df & MS & $\mathrm{F}$ & Source of variation & SS & $\mathrm{df}$ & MS & F \\
\hline$U$. rotundata addition $(\mathrm{U})$ & 2.183 & 2 & 1.091 & $3.008^{*}+$ & Ulva addition (U) & 8.603 & 2 & 4.302 & $38.411 \cdots$ \\
\hline I. obsoleta (I) & 31.997 & 1 & 31.997 & $88.178^{\cdots} \cdot$ & Ilyanassa (I) & 8.106 & 1 & 8.106 & $72.375^{\cdots}$ \\
\hline H. totteni $(\mathrm{H})$ & 2.646 & 1 & 2.646 & $7.292^{\cdots}$ & Hydrobia $(\mathrm{H})$ & 34.068 & 1 & 34.068 & $304.179 \cdots$ \\
\hline U-I Interaction & 1.118 & 2 & 0.559 & $1.141^{+}$ & U-I Interaction & 0.194 & 2 & 0.097 & 0 . \\
\hline I-H Interaction & 2.336 & 1 & 2.336 & $6.439^{\circ}$ & $\mathrm{I}-\mathrm{H}$ Interaction & 0.001 & 1 & 0.001 & $25.152 \cdots$ \\
\hline $\mathrm{U}-\mathrm{H}$ Interaction & 2.280 & 2 & 1.140 & $3.141^{\circ}+$ & U-H Interaction & 5.534 & 2 & 2.817 & $0.866^{+}$ \\
\hline Interaction term & 2.810 & 2 & 1.405 & $3.872^{\circ}$ & Interaction term & 1.458 & 2 & 0.729 & $6.509^{\cdots}$ \\
\hline Error & 13.063 & 36 & 0.363 & & Error & 202.809 & 1812 & & \\
\hline$\cdot \mathrm{p}<.05$ & \multicolumn{9}{|c|}{$\cdots p<.001$} \\
\hline$\cdot+p=.06$ & \multirow{2}{*}{\multicolumn{9}{|c|}{$+p>.05$}} \\
\hline$\because p<.01$ & & & & & & & & & \\
\hline
\end{tabular}


Table 3. Standing stock of bacteria (for each treatment, $\mathrm{n}=4$ ) after $6 \mathrm{wk}$ in the laboratory, as a function of Ulva rotundata detritus input, Ilyanassa obsoleta presence, and Hydrobia totteni density

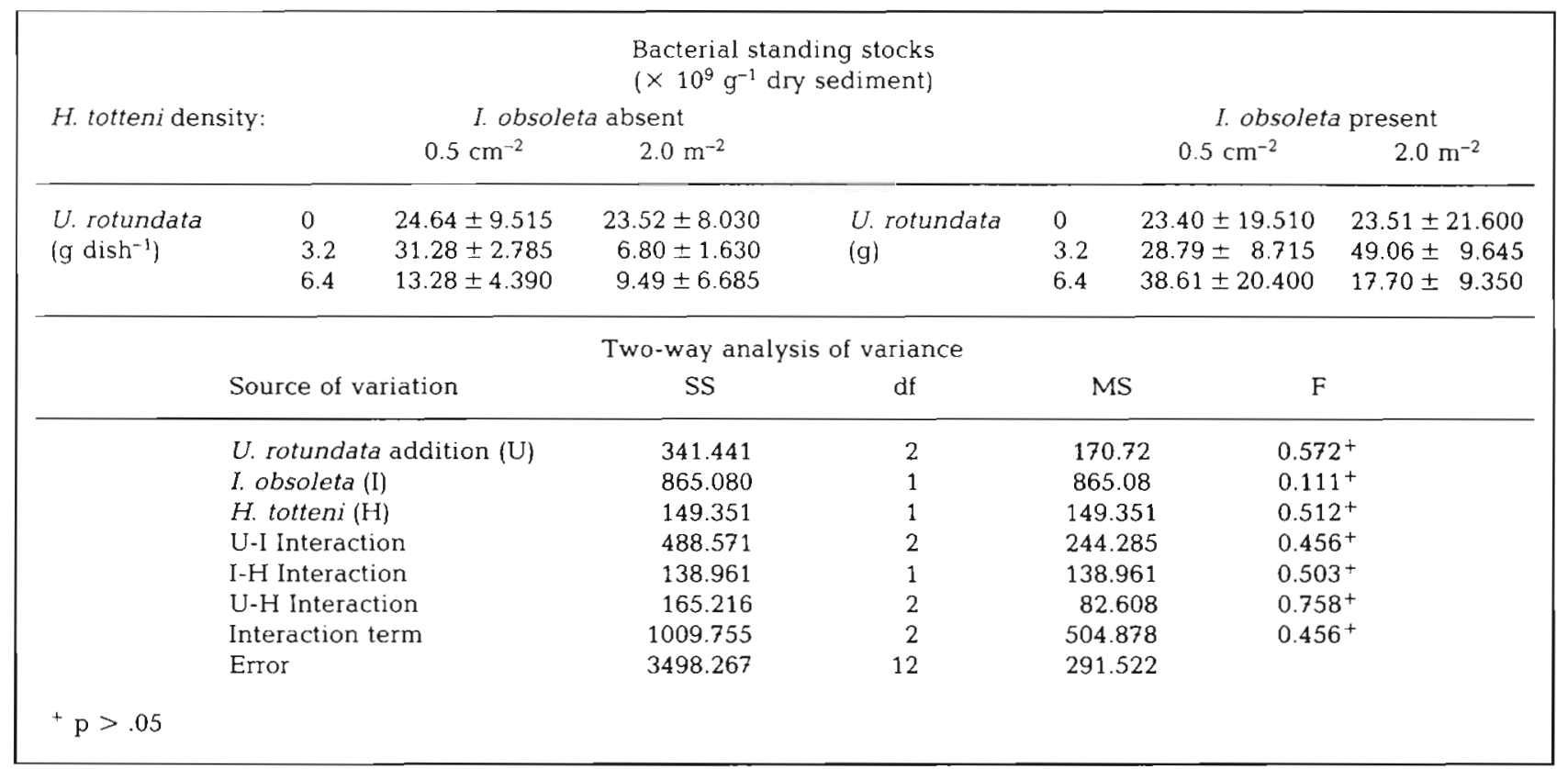

growth. In the intermediate detritus addition, the same time course occurs, except diatom abundance increases dramatically between 10 and $16 \mathrm{wk}$ in the low Hydrobia totteni density-no $I$. obsoleta treatment. At high detritus addition, the same dramatic increase occurs between the 6 and $10 \mathrm{wk}$ samplings, and a similar increase occurs after 10 wk for the high $H$. totteni-no $I$. obsoleta treatment. Referring back to Fig. 1 and 4, both the largest final diatom counts and greatest degree of $H$. totteni growth occurred at inter- mediate detritus addition-low $H$. totteni density-no I. obsoleta condition.

\section{DISCUSSION}

Both field and laboratory experiments demonstrate that additions of detritus derived from the sea lettuce Ulva rotundata may subsidize benthic diatom standing stocks. In the field experiments, additions of sea let-
Fig. 2. Hydrobia totteni. Shell length after 14 wk as a function of density, presence of the larger gastropod Ilyanassa obsoleta, and varying additions of Ulva rotundata detritus. ( $\mathrm{N}=$ no addition, $\mathrm{M}=3.2 \mathrm{~g}$ dish $^{-1}, \mathrm{H}=6.4 \mathrm{~g}$ dish $^{-1}$ ). Starting mean length was $2.47 \mathrm{~mm}$. See Table 2 for statistical analysis

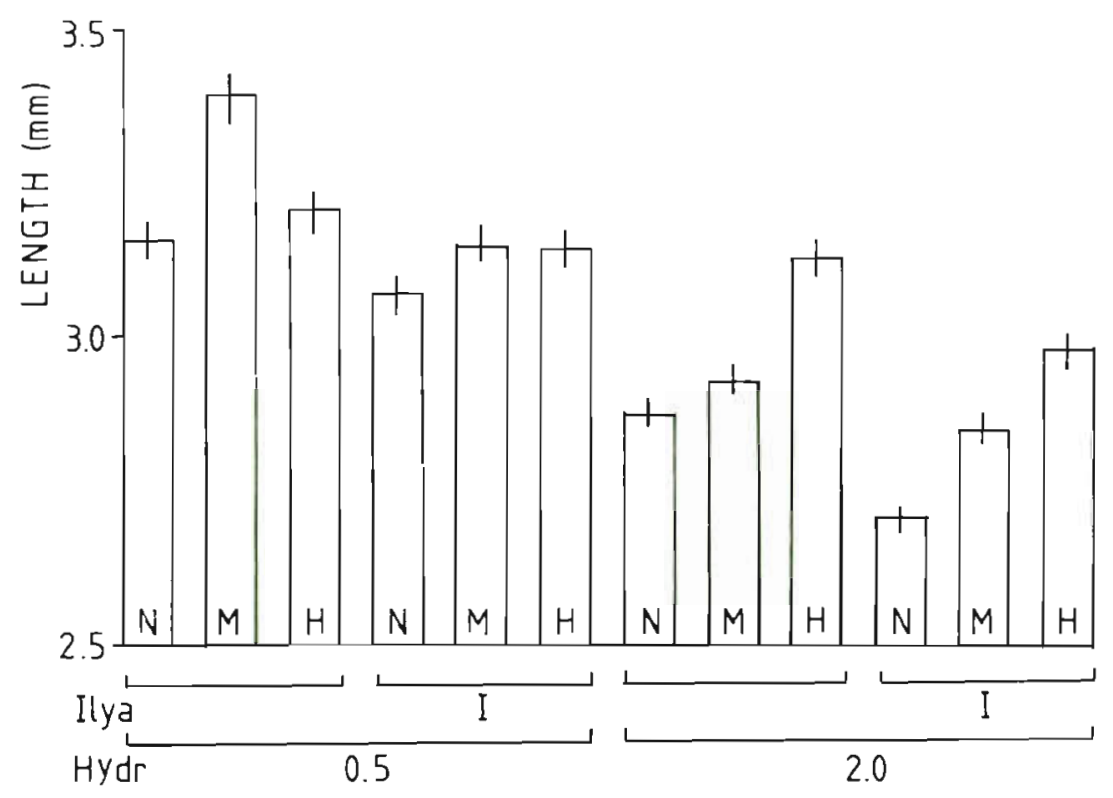




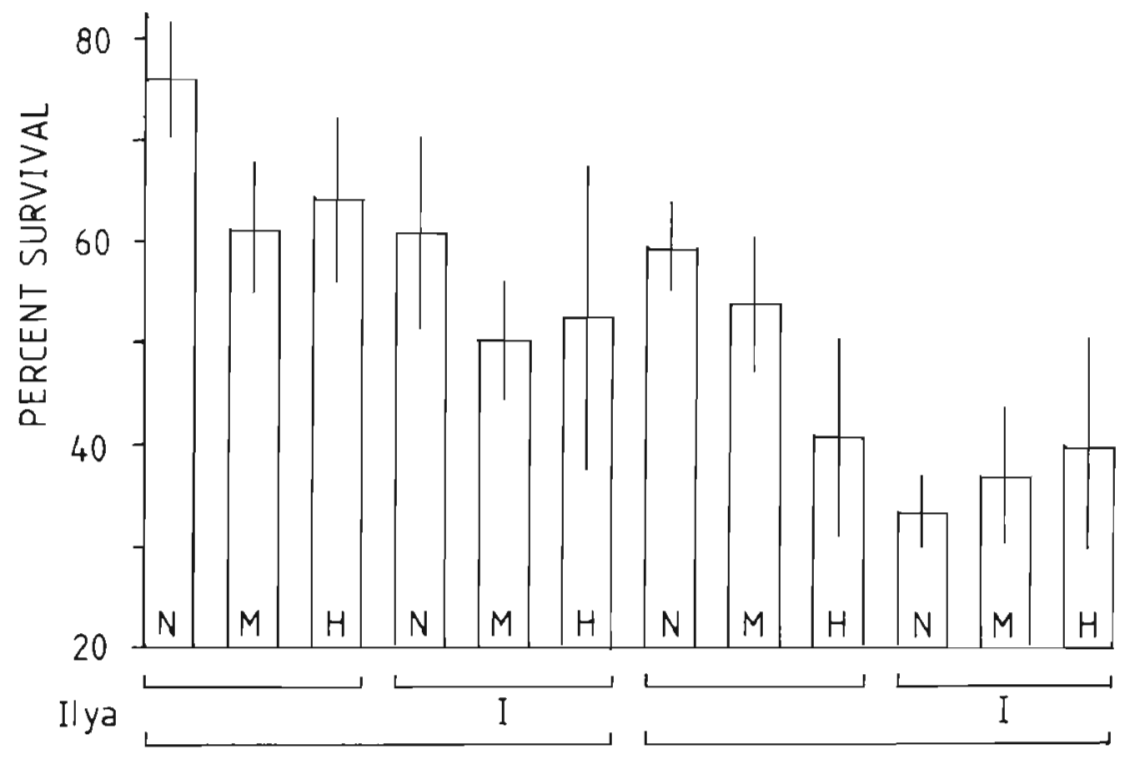

Hydr

0.5

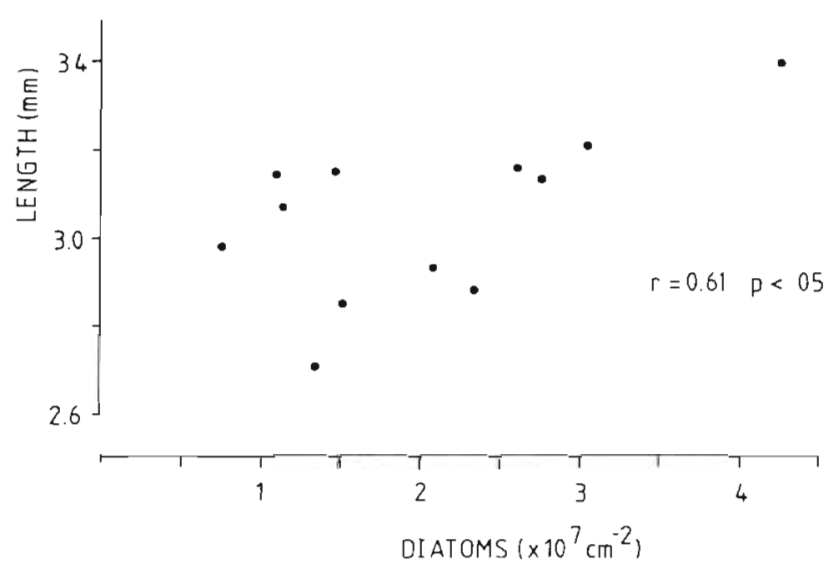

Fig. 4. Relation between diatom standing abundance after $14 \mathrm{wk}$ and shell length of Hydrobia totteniover all treatments (each point is a mean of 4 replicates)

tuce detritus were followed by a brief period where the sediment was obviously anoxic at the surface; diatoms were probably depressed at this time. The same effect was documented quantitatively in the laboratory. Detritus addition depressed diatom standing stock, irrespective of Hydrobia totteni density or Ilyanassa obsoleta presence. The subsequent development, however, was more interesting. At intermediate sea lettuce detritus addition, the treatment with lowest grazing intensity (low Hydrobia-absent Ilyanassa) was the only one to show an eventual strong recovery of diatom growth. At the highest detritus addition, the 2 treatments with less grazing intensity (both $H$. totteni treatments, without $I$. obsoleta) recovered and diatom abundance increased strongly over the treatments without any detritus addition. This suggests that sea
Fig. 3. Hydrobia totteni. Percent mortality after 14 wk as a function of density, presence of the larger gastropod Ilyanassa obsoleta, and varying additions of Ulva rotundata detritus $(\mathrm{N}=$ no addition, $\mathrm{M}=3.2 \mathrm{~g} \mathrm{dish}^{-1}, \mathrm{H}=6.4 \mathrm{~g}$ dish $^{-1}$ )

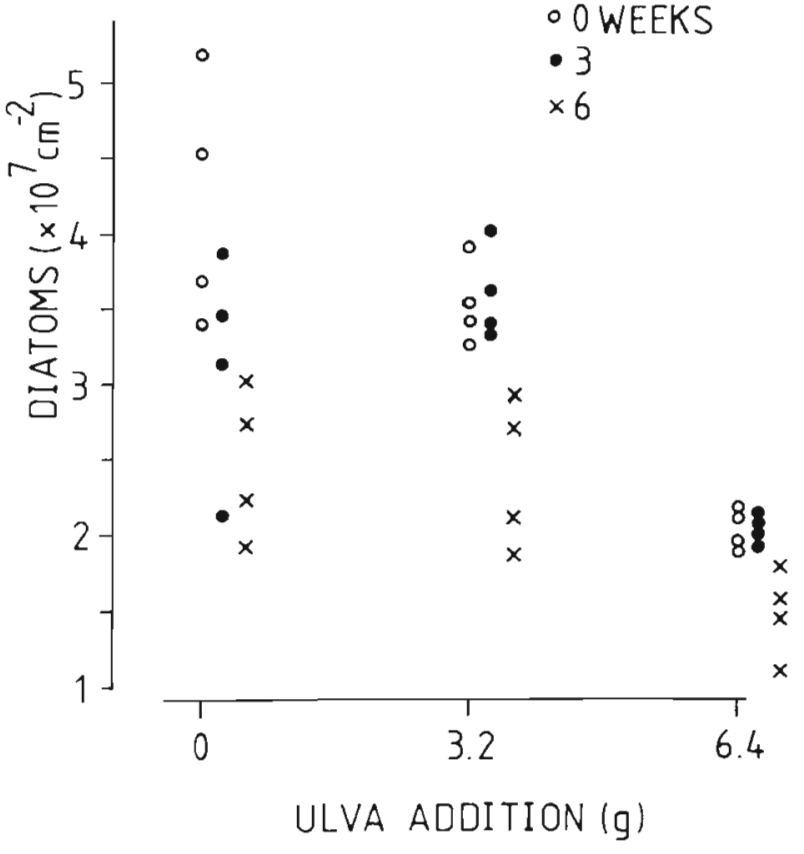

Fig. 5. Relation between diatom standing abundance and level of Ulva rotundata detritus addition in the laboratory for the first 3 sampling periods

lettuce additions subsidized diatom growth and that high grazing (treatments with $I$. obsoleta) prevented the diatom populations from recovering. Our data suggest a lag time, after which decomposition rendered dissolved nutrients available to diatoms (Tenore \& Hanson 1980). Apparently the lag time was much longer in the laboratory ( 6 to $14 \mathrm{wk}$ ) than in the field ( 2 to $3 \mathrm{wk}$ ). This may be explained by tidal stirring in the field, which may have ameliorated the anoxic condi- 
Fig. 6. Time course of diatom standing abundance as a function of varying Hydrobia totteni density and presence of Ilyanassa obsoleta; no Ulva rotundata detritus added

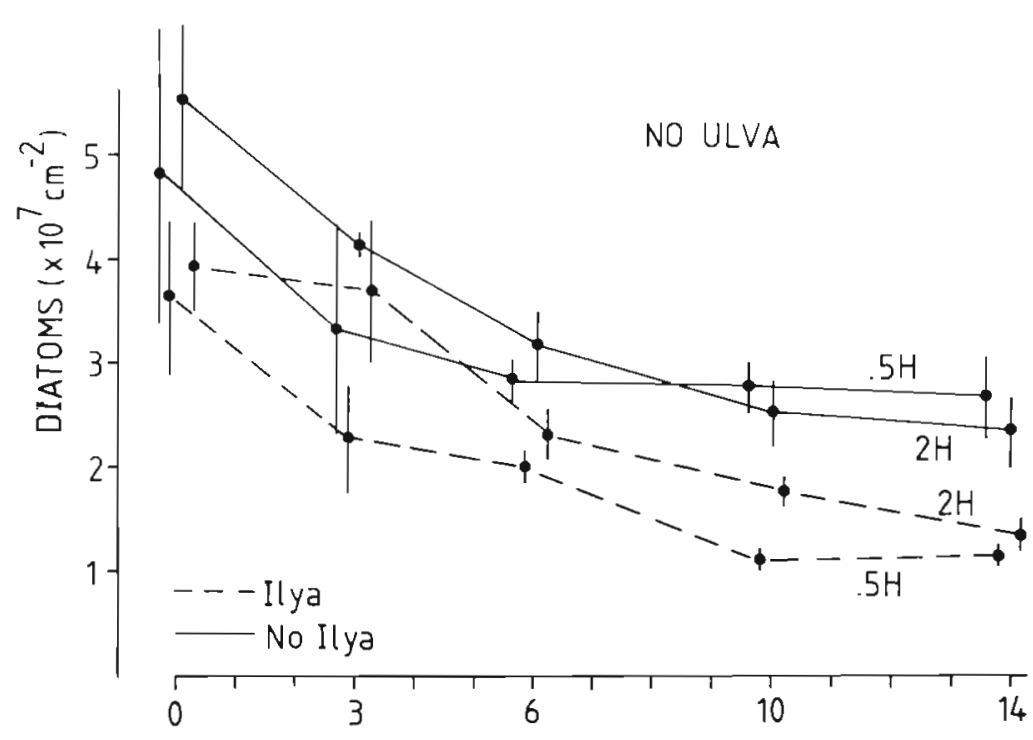

TIME (WEEKS)

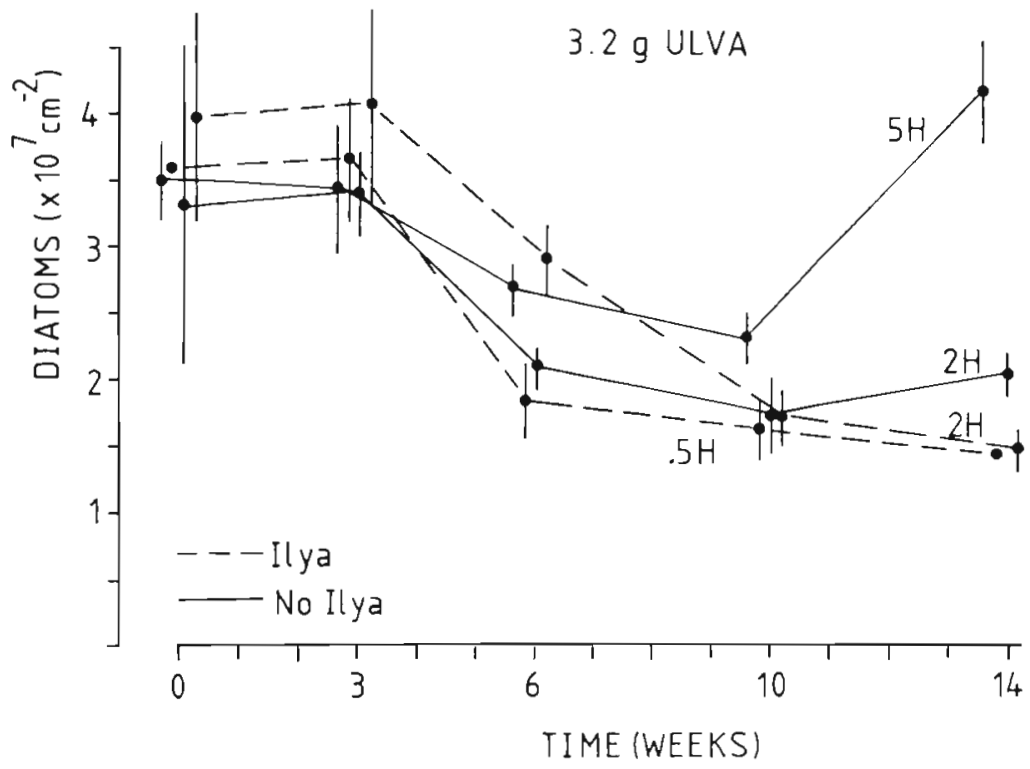

Fig. 7. Time course of diatom standing abundance as a function of varying Hydrobia totteni density and presence of llyanassa obsoleta;

$3.2 \mathrm{~g}$ of Ulva rotundata detritus added

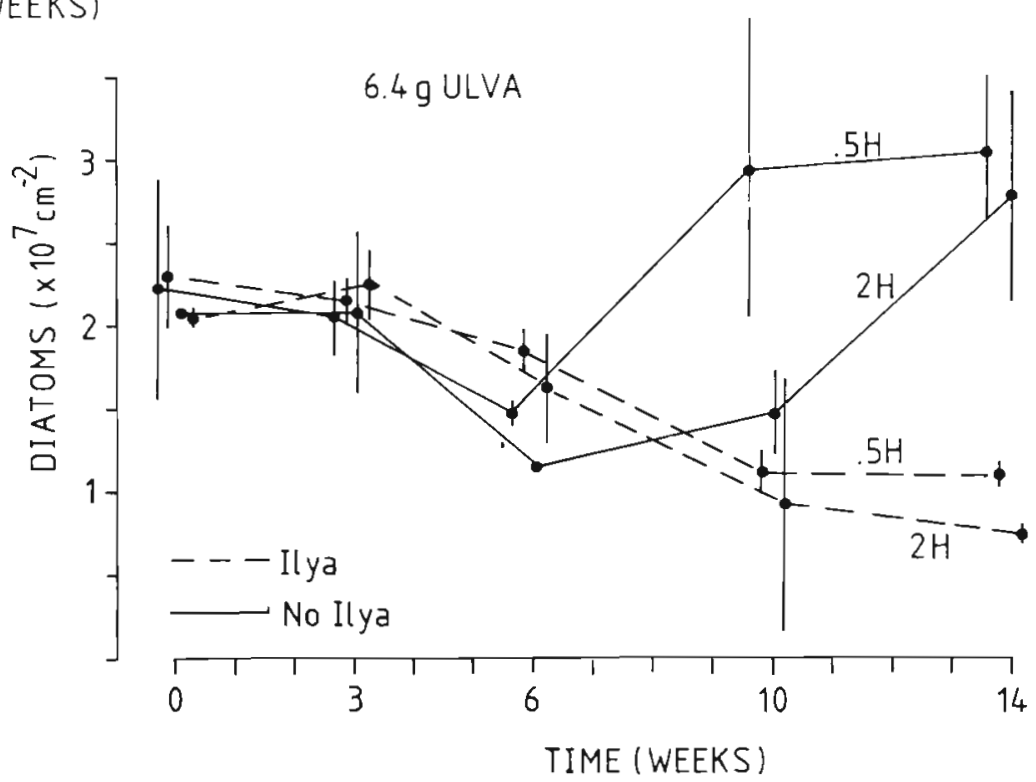

Fig. 8. Time course of diatom standing abundance as a function of varying Hydrobia totteni density and presence of Ilyanassa obsoleta;

$6.4 \mathrm{~g}$ of Ulva rotundata detritus added 
tions that depressed diatom growth. Alternatively, some of the detritus may have been transported away, the remainder subsidizing the diatoms.

As might be concluded from the significant correlation between diatom standing stock and Hydrobia totteni final length, diatom abundance contributed significantly to snail growth. A careful study of assimilation in another species of Hydrobia demonstrates high efficiency for diatoms (Kofoed 1975). Ulva rotundata detritus may have been consumed and assimilated directly; we are now investigating this possibility (see also Findlay \& Tenore 1982, Lopez \& Cheng 1983). In these experiments, however, it seems unlikely that $U$. rotundata detritus was important in $H$. totteni growth, except through the indirect route of subsidizing the benthic diatoms. $H$. totteni growth was not greater in the detritus addition treatments, except where diatom abundance was increased as well. Best growth was obtained in the low Mydrobia-no Ilyanassa treatment, where diatoms were most abundant but detrital addition was intermediate. High levels of $U$. rotundata did not increase growth disproportionately to their increase of diatom abundance. It is possible that Ilyanassa obsoleta was able to digest the detritus and therefore eliminated the possibility of detrital subsidy of the diatoms.

Although there is a significant relation between $\mathrm{HY}$ drobia totteni growth and diatoms, only about $36 \%$ of the total variance in growth can be explained in this way. This provides wide latitude for the importance of other factors. A strong candidate is interspecific and intraspecific interference. $H$. totteni feeding rates are strongly depressed under high density; $H$. totteni feeding rate decreases dramatically above 1 snail $\mathrm{cm}^{-2}$ (Levinton 1979, J. Levinton unpubl.). The effect of interference is especially likely in the conditions without Ulva rotundata addition, as little difference in algal standing stock could be detected among the $2 \mathrm{H}$. totteni densities, though growth was depressed at the higher density. Overall, intraspecific interference is more likely than algal abundance to contribute to the majority of growth in $H$. totteni, simply because about $67 \%$ of the variation in $H$. totteni growth due to the independent factors is explained by $H$. totteni density, while only $7.5 \%$ of the total algal variance can be explained by $H$. totteni. The case for Ilyanassa obsoleta is more difficult to explain, as this species also strongly depresses diatom standing stock (see also pace et al. 1979) and can digest algae not accessible to $H$. totteni (Bianchi \& Levinton 1981). But its contribution to the overall variance in algal density (Table 2 ) is much greater than its contribution to the variance in $H$. totteni growth (Table 3). In field densities on the Flax Pond mudflat under study, $I$. obsoleta occurs at densities that might actually stimulate microalgal pro- ductivity and standing stock (as in Connor et al. 1982). The companion paper to this contribution will demonstrate another strong interference effect - emigration of $I$. obsoleta on $H$. totteni.

We have not mentioned the bacteria data in great detail because of our focus on Hydrobia totteni growth and nutrition, where diatoms are liable to be more important (Fenchel \& Kofoed 1976, Jensen \& Siegismund 1980, Levinton \& Bianchi 1981). The lack of a measurable bacterial response to detritus addition in both field and laboratory is enigmatic. It is likely that a measure of bacterial productivity, as opposed to our measure of standing abundance, would have shown a response to detritus addition. In the case of deposit-feeders where the sediment is fairly slowly relative to the rate of microbial growth, the standing stock of microbes is relevant to the steady state availability of food abundance (Levinton \& Bianchi 1981). But for studies of decomposition dynamic measures are preferable.

The currently accepted model of deposit-feeder nutrition (Newell 1965, Fenchel 1970, Hargrave 1970) suggests that microbial organisms are the principal source of nutrition for deposit feeders and that detritus is usually too refractory for direct consumption. Detritus is not thought to be of direct use unless it is coverted into usable microbial food. Bianchi \& Levinton (1984) presented data supporting the contention that most particulate matter found in sediments adjacent to Spartina marshes does not influence the growth of Hydrobia totteni and, by extension, most other deposit feeders. Rice (1982) argued from a geochemical perspective that sedimentary nitrogen in intertidal sediments is largely inaccessible to digestion and assimilation. Nevertheless, Tenore and others (Tenore 1977. Tenore et al. 1979) demonstrated that detrital inputs can have a strong positive effect on the growth and regulation of deposit feeder populations. Tenore \& Rice (1980) and Tenore et al. (1982) presented conceptual approaches that allow for variations in the effect of detrital input on a consumer community. Our data plot a possible direct route between detrital input and microbial food for deposit feeders. These results only strengthen Cammen's (1982) conclusion that simple indices such as particle surface area may be insufficient to estimate microbial food availability, without additional measures of usable organic matter in a given particle size fraction.

In the period 1972-1982 I observed qualitatively a common seasonal trend in abundance of Ulva rotundata on the mud flat at Flax Pond. While relatively rare in summer and fall, $U$. rotundata grows luxuriantly between the mid-intertidal and subtidal in the winter. In spring, the algae often dies in situ and much of it probably decomposes. This may be one important nutrient source for the large-scale colonization in May by 
the oligochaete Paranais litoralis (Levinton \& Stewart 1982, Stewart, unpubl.), and may be important as adult Hydrobia totteni lay eggs and reproduce later in the early summer (Levinton \& Bianchi 1981). Also at this time (May-June) Ilyanassa obsoleta migrate back to the low and mid-intertidal after spending the winter below low water. This sets the stage for a complex set of interactions involving detrital subsidy of microbial standing stock, food limitation of deposit feeders such as $H$. totteni (Levinton \& Bianchi 1981), and interference interactions among coexisting species (Levinton \& Stewart 1982, Levinton et al. 1984b). We have no data as yet on the role of predation, which may be important as well. This very complexity requires a coordinated laboratory and field experimental approach to document the interactions. It is therefore not possible to understand the community structure of deposit feeders without the combined trophic and interference-species interaction approaches to benthic ecology.

In summary, the growth of Hydrobia totteni can be affected significantly by intraspecific and interspecific interference effects, variation in microalgal abundance, and detrital input. Detrital input apparently subsidizes diaton growth, which in turn provides more food to the snails. Both factors operate in the laboratory at abundances of Ilyanassa obsoleta, H. totteni and diatoms observed commonly in the field. I therefore conclude that resource limitation of in-field populations of $H$. totteni is both complex and significant.

Acknowledgements. I thank Nogiyuki Yamamoto, Steve Stewart, and Dave Berg for help in the field and laboratory. I am very grateful to Jacques Soyer, Director, Laboratoire Arago, for hospitality and facilities. Supported by a grant from the US National Science Foundation (Biological Oceanography). Contribution number 515 to the Graduate Studies in Ecology and Evolution, State University of New York at Stony Brook.

\section{LITERATURE CITED}

Bianchi, T. S., Levinton, J. S. (1981). Nutrition and food limitation of deposit-feeders. II. Differential effects of Hydrobia totteni and llyanassa obsoleta on the microbial community. J. mar. Res. 39: 547-556

Bianchi, T. S., Levinton, J. S. (1984). The importance of microalgae bacteria and particulate organic matter in the somatic growth of Hydrobia totteni. J. mar. Res. 42: $431-443$

Brenchley, G. A., Carlton, J. T. (1983) Competitive displacement of native mud snails by introduced periwinkles in the New England intertidal zone. Biol. Bull. mar. biol. Lab., Woods Hole 165: 543-558

Cammen, L. M. (1980). The significance of microbial carbon in the nutrition of the deposit-feeding polychaete Nereis succinea. Mar. Biol. 61: 9-20

Cammen, L. M. (1982). Effect of particle size on organic content and microbial abundance within four marine sediments. Mar. Ecol. Prog. Ser. 9: 273-280
Connor, M. S., Teal, J. M., Valiela, I. (1982). The effect of feeding by mud snails, llyanassa obsoleta Say, on the structure and metabolism of a laboratory benthic algal community. J. exp. mar. Biol. Ecol. 65: 29-45

Dale, N. G. (1974). Bacteria in intertidal sediments: factors related to their distribution. Limnol. Oceanogr. 19: $509-518$

Fenchel, T (1970). Studies on the decomposition of organic detritus derived from the turtle grass Thallassia testudinum. Limnol. Oceanogr 15: 14-20

Fenchel, T., Kofoed, L. H., (1976). Evidence for exploitative interspecific competition in mud snails. Oikos $27: 367-376$

Findlay, S., Tenore, K. R. (1982). Nitrogen source for a detritivore: detritus substrate versus associated microbes. Science 218: 371-373

Hanson, R. B. (1980). Measuring microbial activity to assess detrital decay and utilization. In: Tenore, K. R., Coull, B. C. (ed.) Marine benthic dynamics. University of South Carolina Press, Columbia, p. 347-354

Hargrave, B. T. (1970). The utilization of benthic microflora by Hyallela azteca (Amphipoda). J. Anim. Ecol. 35: $427-437$

Jensen, K. T., Siegismund, H. R. (1980). The importance of diatoms and bacteria in the diet of Hydrobia species. Ophelia 17 (Suppl.): 193-199

Kofoed, L. H. (1975). The feeding biology of Hydrobia ventrosa Montagu. I. The assimilation of different components of the food. J. exp. mar. Biol. Ecol. 19: 233-241

Levinton, J. S., (1977). The ecology of deposit-feeding communities: Quisset Harbor, Massachusetts. In: CouII, B. C. (ed.) Ecology of marine benthos. University of South Carolina Press, Columbia, p. 191-228

Levinton, J. S. (1979). The effect of density upon depositfeeding populations: moving, feeding, and floating of Hydrobia ventrosa Montagu (Gastropoda, Prosobranchia). Oecologia 43: 27-39

Levinton, J. S. (1980). Particle feeding by deposit feeders: models, data, and a prospectus. In: Tenore, K. R., Coull B. C. (ed.) Marine benthic dynamics. University of South Carolina Press, Columbia, p. 423-429

Levinton, J. S., Bianchi, T. S. (1981). Nutrition and food limitation of deposit-feeders. I. The role of microbes in the growth of mud snails (Hydrobiidae). J. mar. Res. 39: $531-545$

Levinton, J. S., Bianchi, T. S., Stewart, S. (1984a). What is the role of particulate organic matter in benthic invertebrate nutrition? Bull. mar. Sci., in press

Levinton, J. S., Stewart, S. (1982). Marine succession; the effect of two deposit-feeding gastropod species on the population growth of Paranais iitoralis Muller 1784 (Oligochaeta). J. exp. mar. Biol. Ecol. 59: 231-241

Levinton, J. S., Stewart, S., DeWitt, T. (1984b). Complex interactions of a deposit feeder with its resources. 2. Field and laboratory experiments on interference between $\mathrm{Hy}$ drobia totteni and Ilyanassa obsoleta (Gastropoda) and its possible relationship to seasonal shifts in vertical zonation on mudflats. Mar. Biol., in press

Lopez, G. R., Cheng, I.-J. (1983). Synoptic measurements of ingestion rate, ingestion selectivity, and absorption efficiency of natural foods in the deposit-feeding molluscs Nucula annulata (Bivalvia) and Hydrobia totteni (Gastropoda). Mar. Ecol. Prog. Ser. 11: 55-62

Newell, R. C. (1965). The role of detritus in the nutrition of two marine deposit feeders, the prosobranch Hydrobia ulvae and the bivalve Macoma balthica. Proc. Zool. Soc. Lond. 144: 25-45

Pace, M. L., Shimmel, S., Darley, W. M. (1979). The effect of 
grazing by a gastropod, Nassarius obsoletus, on the benthic microbial community. Estuar. coast. mar Sci. 9: $121-134$

Peterson, C. H. (1977). Competitive organization of the softbottom macrobenthic communities of southern California lagoons. Mar. Biol. 43: 343-359

Race, M. S. (1982). Competitive displacement and predation between introduced and native mud snails. Oecologia 54 : $337-347$

Rhoads, D. C., Young, D. K. (1970). The influence of depositfeeding organisms on sediment stability and community trophic structure. J. mar. Res. 28: 150-178

Rice, D. L. (1982). The detritus nitrogen problem: new observations and perspectives from organic geochemistry. Mar. Ecol. Prog. Ser. 9: 153-162

Taghon, G. L., Jumars, P. A. (1984). Variable ingestion rate and its role in optimal foraging behavior of marine deposit feeders. Ecology 65: 549-558

Tenore, K. R. (1975). Detrital utilization by the polychaete Capitella capitata. J. mar. Res. 33: 261-274

Tenore, K. R. (1977). Growth of Capitella captitata cultured on various levels of detritus derived from different sources. Limnol. Oceanogr. 22: 936-941

Tenore, K. R., Cammen, L., Findlay, S., Phillips, N. (1982). Perspectives of research in detritus: do factors controlling availability of detritus to consumers depend on its source? J. mar. Res. 40: 473-490

Tenore, K. R., Hanson, R. B. (1980). Availability of different detritus with aging to a polychaete macroconsumer, Capitella capitata. Limnol. Oceanogr. 25: 553-558

Tenore, K. R., Hanson, R. B., Dornseif, B. E., Weiderhold, C. N. (1979). The effect of organic nitrogen supplement on the utilization of different sources of detritus. Limnol Oceanogr. 24: 350-355

Tenore, K. R., Rice, D. L. (1980). Trophic factors affecting secondary production of deposit-feeders. In: Tenore, K. R. Coull, B. C. (ed.) Marine benthic dynamics. University of South Carolina Press, Columbia, p. 325-340

Wells, F. E. (1978). The relationship between environmental variables and the density of the mudsnail Hydrobia totten in a Nova Scotia salt marsh. J. mollusc. Stud. 44: 120-129

Whitlatch, R. B. (1974). Food resource partitioning in the deposit-feeding polychaete Pectinaria gouldi. Biol. Bull. mar. biol. Lab., Woods Hole 147: 227-235

Woodin, S. A. (1974). Polychaete abundance patterns in a marine soft-sediment environment: the role of biological interactions. Ecol. Monogr. 44: 171-187

Zobell, C. E., Feltham, C. B. (1938). Bacteria as food for certain marine invertebrates. J. mar. Res. 1: 312-327

This paper was presented by Professor R. C. Newell; it was accepted for printing on November 29, 1984 